\title{
Pengembangan Bahan Ajar Matematika Materi Bilangan berbasis Higher Order Thinking Skills (HOTS)
}

\author{
Siti Munawaroh ${ }^{1}$, I Nyoman Sudana Degeng ${ }^{2}$, Nurmida Catherine Sitompul ${ }^{3}$ \\ ${ }^{1,3}$ Teknologi Pendidikan, Pascasarjana, Universitas PGRI Adi Buana Surabaya \\ ${ }^{1}$ Guru Matematika SMP Negeri 20 Surabaya, ${ }^{2}$ Teknologi Pendidikan Universitas Negeri Malang
}

\section{Edcomtech}

Jurnal Kajian

Teknologi Pendidikan

Volume 6, No 1, April 2021

124-139

Submitted 03-05-2020

Accepted 12-05-2020

Corresponding Author

Siti Munawaroh

munawarohamel@gmail.com

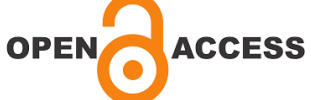

\begin{abstract}
Abstrak
Pengembangan Bahan ajar Matematika Materi Bilangan Berbasis High Order Thinking Skills (HOTS) untuk siswa SMP dimaksudkan untuk memberikan salah satu jawaban terhadap kurangnya buku pendamping pembelajaran Matematika materi bilangan yang mengimplementasi kurikulum 2013 serta keterbatasan guru dalam mengembangkan strategi pembelajaran berorientasi HOTS dan adanya tuntutan untuk peserta didik yang selalu membiasakan diri berpikir kritis,analitis, memecahkan masalah dan meningkatkan kreativitas. Penelitian ini menggunakan metodologi penelitian Research and Development $(R \& D)$ dimana peneliti membatasi penelitian dalam skala kecil, termasuk untuk membatasi langkah penelitian. Hasil validasi diperoleh bahwa secara keseluruhan ahli desain memberi skor rata-rata 4,7. Ahli media memberi skor rata rata 4,7. Guru matematika memberi skor rata rata 3,84 dan angket respon siswa (Uji kelompok kecil) mendapat skor 4,5 berdasarkan data dan analisis yang dilakukan menyatakan produk bahan ajar ini sangat layak digunakan sebagai buku pendamping pembelajaran Matematika berbasis HOTS
\end{abstract}

Kata Kunci: pengembangan bahan ajar, Higher Order Thinking Skills, Pembelajaran matematika

\begin{abstract}
Development of Mathematics Teaching Materials for Numbers Based on High Order Thinking Skills (HOTS) for junior high school students is intended to provide one answer to the lack of a companion Mathematics learning companion number material that implements the 2013 curriculum and the limitations of teachers in developing HOTS-oriented learning strategies and the existence of demands for students who always accustom themselves to think critically, analytically, solve problems and increase creativity. This research uses Research and Development $(R \& D)$ research methodology where researchers limit research on a small scale, including to limit the research steps. Validation results obtained that overall design experts gave an average score of 4.7. Media experts score an average of 4.7. Mathematics teachers gave an average score of 3.84 and the student response questionnaire (small group test) received a score of 4.5 based on the data and analysis conducted which stated that this teaching material product was very suitable to be used as a companion book for HOTS-based Mathematics learning.
\end{abstract}

Keywords: Development of teaching materials, Higher Order Thinking Skills, Mathematics learning 


\section{LATAR BELAKANG}

Saat ini kita berada pada era dimana kemajuan pesat Ilmu Pengetahuan dan Teknologi mengakibatkan berubahnya cara berkehidupan manusia. Segala hal terjadi begitu cepat dan tidak terduga akibat digitalisasi, otomatisasi menuntut kita meningkatkan keterampilan keterampilan baru untuk mengimbangi perubahan tersebut (Sitompul, Leksono, \& Rufi'i, 2019). Perubahan itulah yang mendorong perubahan dalam sistem pendidikan. Sejalan dengan itu Pemerintah menyusun kurikulum yang berbasis pengembangan kemampuan memecahkan masalah, berpikir kreatif dan pengolahan informasi yaitu kurikulum 2013. Melalui kebijakan penerapan kurikulum 2013 yang menggunakan pendekatan Saintifik diharapkan semua pembelajaran bermuara pada pengembangan keterampilan menalar, membandingkan dan mengolah pikiran tingkat tinggi atau dikenal dengan Higher Order Thinking Skills (HOTS). Implementasi Kurikulum 2013 sejauh ini sudah 3 kali mengalami revisi, ini menunjukkan keseriusan pemerintah untuk menyiapkan anak bangsa menyongsong masa depan. Falsafah dan pedoman hidup bangsa dapat dicerminkan melalui kurikulum. Tujuan arah serta kualitas hidup masa depan berbangsa dan bernegara ini akan ditentukan oleh penerapan kebijakan kurikulum yang digunakan oleh bangsa tersebut sekarang. Segala perubahan harus dapat diantisipasi oleh kurikulum, karena hanya melalui pendidikan sebagai salah satu cara yang paling ampuh untuk mengiringi tersebut (Alfa, 2017). Pada kenyataaan implementasi nya tidak bisa dilepaskan tanpa peran guru, sedangkan pemerintah sangat mendorong pengembangan HOTS dalam pengajaran dikelas, terbukti dengan meningkatnya bobot soal UNBK standar internasional sudah mulai diterapkan, mencakup soal-soal Matematika, literasi, ataupun untuk soal IImu Pengetahuan Alam yaitu yang memerlukan tingkat pemahaman, daya nalar dan daya pikir tinggi, atau dikenal HOTS (Higher Order Thinking Skills) (Sukmana, 2018).

Penurunan prestasi kejuaraan tingkat internasional kurun waktu tahun 2000 sampai tahun 2015, dalam dunia pendidikan yaitu PISA. Perolehan Tahun 2016, Dilansir dari The Guardian, Indonesia menempati urutan ke-57 dari total 65 negara. Survei ini diterbitkan oleh Organisation for Economic Co-operation and Development (Pellini, 2016). Sehubungan dengan kemampuan dan kompetensi guru, pada bagian ini yang paling utama karena kekuatan terdepan pelaksanaan kurikulum adalah guru. Guru lah yang melaksanakan kurikulum 2013 yang saat ini sedang diimplementasikan. Pelaksanaan Kurikulum ini sudah berlangsung lebih dari tahun. Meskipun demikian, belum semua guru siap mengimplementasikan kurikulum 2013. (Hanik, Mardiyana, \& Rosid, 2020)

Walaupun masih banyak guru belum mengembangkan pembelajaran HOTS secara maksimal. Dengan ditingkatkan bobot soal ini guru dipacu menyelenggarakan proses pembelajaran berbasis HOTS. Model pembelajaran yang mengajak peserta didik berpikir kritis, mampu mengolah informasi yang sering disebut berpikir tingkat tinggi atau Higher Order Thinking Skills ( HOTS), harus selalu dikembangkan dalam proses kegiatan belajar mengajar di sekolah itulah harapan dan himbauan pemerintah. Dengan mengembangkan model itu peserta didik akan terbiasa dan mempunyai kemampuan berkomunikasi dengan baik, keterampilan berpikir kritis, berpikir kreatif selalu mempunyai sikap percaya diri untuk mempersiapkan diri menghadapi era digital milenium. (Harususilo, 2018)

Guru sudah harus memulai langkah langkah pembelajaran yang berpijak dan mewujudkan empat asas dalam belajar yang disarankan oleh Komisi Internasional UNESCO untuk pendidikan (1)belajar untuk mengetahui , (2) belajar untuk mengerjakan , (3) belajar untuk menjadi , (4)belajar untuk hidup bersama . (Daryanto \& Syaiful, 2017). Guru tidak lagi sumber dari segala sumber belajar, guru harus menghilangkan kebiasaan lama dalam mengajar. Tugas guru adalah tidaklah mudah. Penting untuk dicatat bahwa pendidik memiliki tanggung jawab mendalam untuk mendorong peserta didik untuk merefleksikan perubahan sifat, ruang kelas dan kesesuaian pengetahuan terapan. 
Membangun pengetahuan sebagai prinsip panduan mengasumsikan bahwa peserta didik akan menantang teori dan kenyataan yang ada. (MacKinnon \& Aylward, 2009) Guru saat ini hanya memfasilitasi peserta didik dalam belajar. memotivasi dan memberi semangat peserta didik untuk belajar menggunakan kemampuan bernalar, mengolah informasi dan berpikir kritis mempraktekkan berbagai strategi dan metode pembelajarn seperti, penemuan terbimbing, project based learning, investigasi kelompok, inquiry dan lainnya

Sesuai isi Permendikbud No. 22 Tahun 2016 perihal Standar Proses di jelaskan pembentukan perilaku saintifik, sosial serta mengembangkan rasa keingintahuan dapat dicapai jika tiga model kegiatan pembelajaran ini dipraktekkan dan diterapkan. Model-model tersebut adalah Discovery/Inquiry Learning, model Pembelajaran Melalui Penemuan Terbimbing, Problem-based Learning, model Pembelajaran Berbasis Masalah dan Projectbased Learning, Pembelajaran Berbasis Proyek (Ariyana, Pudjiastuti, Bestary, \& Zamroni,, 2019).

Proses pembelajaran saat ini adalah bertujuan untuk meningkatkan kompetensi peserta didik yang mempunyai Kemampuan berpikir, bernalar,analitis, kreatif dan mampu menyelesaikan masalah . Kemampuan mempunyai pola pikir kritis diperlukan untuk membedakan dan memilah informasi tersebut layak diterima atau perlu dikaji ulang. Berpikir kritis salah satu komponen dari berpikir tingkat tinggi. Dengan membiasakan peserta didik melakukan pemikiran kritis, berpikir kreatif, dan pemecahan masalah maka pada akhirnya peserta didik terbiasa berpikir sehingga mempunyai keterampilan berpikir tinggi atau Higher order Thinking Skills (HOTS)

Pengembangan kemampuan peserta didik untuk memiliki keterampilan berolah pikir yang kompleks adalah merupakan tujuan utama proses pembelajaran matematika. keterampilan berolah pikir yang kompleks atau dikenal higher order thinking Skills atau keterampilan berpikir tingkat tinggi. kemampuan memecahkan masalah, kemampuan berpikir kreatif dan kemampuan berpikir kritis adalah merupakan bagian dari Higher Order Thinking Skills atau HOTS (Brookhart, 2010)

Benjamin S. Bloom adalah seorang psikolog pendidikan dari Amerika Serikat, dia beserta kawan kawannya adalah orang yang pertama mengenalkan konsep pemikiran belajar Higher Order Thinking Skills (HOTS) dalam bukunya yang bertajuk Taxonomy of Educational Objectives: The Classification of Educational Goals (1956) di dalamnya berisi kategori berbagai tingkat pemikiran bernama Taksonomi Bloom, mulai dari level paling bawah sampai dengan level paling tinggi. Keterampilan Level paling bawah dalam proses pembelajaran itu mencakup mengingat, memahami, dan menerapkan Menurut Bloom, keterampilan dibagi menjadi dua bagian. dan keterampilan kedua level paling tinggi adalah yang dikategorikan ke dalam keterampilan berpikir tingkat tinggi berupa keterampilan menganalisis, mengevaluasi, dan mencipta. (Ariyana, Pudjiastuti, Bestary, \& Zamroni,, 2019). Pendapat para pakar tentang ini, pengertian keterampilan berpikir tingkat tinggi dari Lauren B. Resnick adalah proses berpikir kompleks dalam menguraikan secara rinci materi, menarik kesimpulan, membangun representasi, menganalisis permasalahan, dan menciptakan hubungan dengan melibatkan aktivitas mental yang paling dasar. (Resnick, 1987)

Krulik dan Rudnick menyatakan bahwa bagian terpenting dan sangat dibutuhkan dari proses pembelajaran matematika dalam keterampilan berpikir tingkat tinggi adalah penalaran (Krulik, Rudnick, \& Mileo, 2003). Kemampuan penalaran ini berkenaan dengan pembelajarannya di kehidupan sehari-hari yang dihadapinya (Qolbi, Thaariq, Az-Zahroh, Anwar, \& Faiza, 2019)

John Dewey berpendapat bahwa jika seseorang berusaha berpikir segalah hal secara mendalam dengan mengerahkan kemampuannya, memulai mengajukan bermacam pertanyaan yang relevan dan akhirnya menemukan informasi yang relevan pula dan tidak hanya menunggu informasi saja, semua itu adalah bagian dari berpikir kritis secara esensial dalam proses aktif (Fisher, 2009). Keterampilan HOT terbaik harus dilakukan melalui kegiatan 
langsung, keterampilan di mana siswa dapat mengarahkan pembelajaran mereka sendiri (Harrison, 2013)

Definisi HOTS dari Pemerintah melalui Kementerian Pendidikan dan Kebudayaan pada dasarnya mengikuti pendapat Brookhart. Untuk membantu proses tersebut diperlukan pengembangan. untuk mendapatkan hasil yang maksimal dalam proses pembelajaran diperlukan peningkatan kualitas cara memilih, menentukan, menetapkan, melaksanakan dan mengembangkan metode pembelajaran

dengan mendesain proses pembelajaran itu. desain itulah bagian dari pengembangan ( (Degeng \& Degeng, 2018). Rancangan buku bahan ajaryang dipilih karena Penelitimemberi tambahan ide dengan mengembangkan bahan ajar sebagai pendamping buku yang ada dengan harapan bahan ajar yang valid, praktis dan efektif untuk memfasilitasi guru dan peserta didik dalam mengembangkan dan mengimplementasikan kurikulum 2013 berbasis HOTS (Higher Order Thinking Skills). Merujuk pendapat Panen (2001) tentang bahan ajar, menurutnya bahwa bahan ajar merupakan kesatuan bahan-bahan atau materi pelajaran yang disusun secara seksama dan sistematis, yang digunakan guru dan peserta didik dalam kegiatan proses belajar mengajar (Sadjati, 2012). Bahan ajar yang yang digunakan sebagai buku pelajaran yang menunjang kegiatan belajar mengajar disusun oleh pakar dalam bidangnya untuk maksud-maksud dan tujuan instruksional yang dilengkapi dengan saran saran pengajaran yang sesuai, dengan tujuan lebih mudah memahami disebut buku ajar (Tarigan, 1986) dalam (Kurbaita, Zulkardi, \& Siroj, 2013)

Salah satu hal harus diperhatikan dalam pembuatan bahan ajar adalah segi bahasa Bahasa yang digunakan sederhana saja yang mudah dicerna karena peserta didik hanya berhadapan dengan bahan ajar ketika belajar secara mandiri dan dapat menuntaskan proses pembelajaran (Puspitasari, 2017). Buku adalah salah satu sarana dalam pembelajaran. Media yang baik juga akan mampu memberikan motivasi dan meningkatkan keterampilan dasar peserta didik (Tinio, 2002) dalam (Utami, Nugroho, Dwijayanti, \& Sukarno, 2018)

Bahan ajar materi bilangan Menurut hasil sebaran UNBK (Ujian Nasional Berbasis Komputer) 2019 tingkat SMP Pusat Penilaian pendidikan Kementerian Pendidikan dan Kebudayaan 2019 untuk capaian materi matematika kota Surabaya Persentase siswa yang menjawab benar soal-soal pada setiap cakupan materi adalah Materi bilangan adalah $51,86 \%$, materi Aljabar adalah 63,54\%, materi Geometri dan Pengukuran 53,82\% dan materi statistika dan peluang adalah $65,78 \%$ disini ditunjukan pada materi Bilangan siswa yang menjawab benar paling sedikit hanya $51,86 \%$ (Pendidikan, Pusat Penilaian, 2018). karena itu pemilihan materi ini dalam mengembangkan Bahan ajar sangat tepat.

\section{METODE}

Jenis penelitian yang dikembangkan oleh peneliti adalah Research and Development (R\&D) dimana hasil akhir penelitian adalah produk yang berupa bahan ajar dalam bentuk buku yang valid sesuai kaidah untuk memfasilitasi pendidik dan peserta didik dalam mengembangkan dan mengimplementasikan kurikulum 2013 berbasis HOTS. Selain itu juga peneliti membuat instrumen penelitian berupa lembar validasi, dan angket tanggapan peserta didik. Model yang dikembangkan dalam penelitian ini adalah pengembangan versi Borg dan Gall dalam (Emzir, 2011) dimana pelaksanaannya disesuaikan dengan kebutuhan peneliti termasuk membatasi langkah langkah penelitian karena beberapa alasan keterbatasan . Hasil penyesuaian prosedur penelitian sebagai berikut; yaitu (1) pengumpulan informasi, (2) perencanaan produk, (3) pengembangan produk, (4) validasi produk, dan (5) evaluasi produk (Yektyastuti \& Ikhsan , 2016) untuk tahap 4 dan 5 peneliti satukan. Jadi uji lapangan dan revisi produk akhir. Model Borg and Gall yang sudah dimodifikasi terlihat pada gambar berikut: 


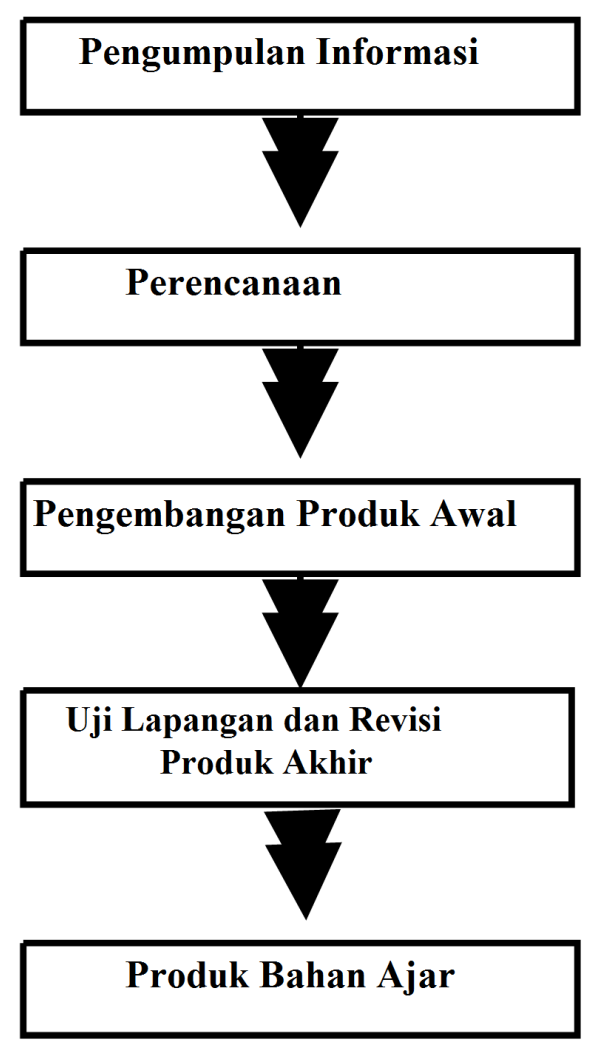

\section{Gambar 1 Prosedur Pengembangan Buku Bahan ajar berbasis HOTS}

Berdasarkan gambar modifikasi model pengembangan Borg and Gall di atas, maka pengembangan produk dalam penelitian ini dimulai dengan Pengumpulan informasi, pada tahap ini yang disiapkan pertama adalah angket untuk studi lapangan, angket ini bertujuan untuk mengumpulkan informasi mengenai kebutuhan apa saja yang dibutuhkan peserta didik dalam pembelajaran yang telah berlangsung. Selain angket alat pengumpulan data berupa materi tanya jawab yang digunakan untuk wawancara kepada guru bidang studi matematika. Hal-hal yang diperhatikan dalam wawancara tersebut terkait dengan implementasi kurikulum 2013 dan model model pembelajaran yang telah diterapkan. Serta tanggapannya terkait buku yang digunakan selama ini. Langkah berikutnya dalam mengumpulkan informasi adalah mengkaji buku yang digunakan melalui sumber sumber yang ada selain informasi dari guru. Jadi pada tahap ini telah dilakukan analisis kebutuhan peserta didik dan analisis materi ajar. Setelah dilakukan pengumpulan informasi peneliti menindaklanjuti dengan merencanakan tindakan, disini adalah tahap perencanaan adapun langkah awal adalah peneliti melakukan pengkajian bahan yang akan disusun dalam bukuajar, yaitu dengancara menganalisis kompetensi inti dan kompetensi dasar; menentukan tujuan pembelajaran, melakukan analisis materi pembelajaran; Pemilihan bahan, menyusun kerangka buku dan menyiapkan kisi-kisi penilaian produk untuk menguji kelayakan produk. Setelah semua sudah terkonsep maka tahap berikutnya adalah mengembangkan Produk awal, dari kerangka dikembangkan menjadi Desain awal buku, dengan mengumpulkan referensi materi bilangan. Selanjutnya memetakan materi, memperdalam materi , menyusun pembelajaran yang berbasis HOTS melalui aktivitas kegiatan siswa atau mengembangkan pembelajaran HOTS dengan memberi stimulus, latihan latihan tantangan yang membutuhkan alur pemecahan permasalahan. Setelah bagian isi buku tersusun dilanjutkan melengkapi semua isi buku termasuk glosarium, kunci jawaban dsb. Kemudian bagian akhir buku yaitu sampul belakang buku.

Setelah buku tersusun peneliti mengembangkan kisi kisi yang telah dibuat sebagai instrumen validasi produk bagi ahli media, ahli desain, guru matematika dan peserta didik. Tahap terakhir adalah melakukan Uji lapangan dan revisi produk akhir. Pada bagian ini produk yang telah dihasilkan pada awal pengembangan divalidasi, orang yang melakukan validasi adalah Ahli di bidangnya yaitu Ahli materi dan Ahli Desain; kemudian dilakukan analisis I dan setelah mendapat masukan dilanjutkan revisi 1 produk yang telah direvisi dikembalikan lagi ke ahli untuk mendapat tanggapan atas perubahan yang telah dilakukan dan hasilnya akan direvisi lagi, setelah mendapat masukan kedua dari ahli dilanjutkan Tahap validasi yang dilakukan oleh guru matematika; maka hasil penilaian dianalisis lanjut revisi kedua, setelah itu Uji coba produk pada peserta didik; dan Revisi Produk akhir. Pengujian produk dilakukan pada kelompok kecil yang terdiri 5 peserta didik dan memberikan tanggapan dan respon tertulis yang diberikan sebagai bahan evaluasi sehingga menjadi produk bahan 
ajar yang layak serta sesuai digunakan dalam pembelajaran.

\section{Data, Instrumen Penelitian, Analisis Data}

Penggolongan data pada penelitian ini adalah data sebelum pembuatan bahan ajar yang berupa angket tanggapan peserta didik pada proses pembelajaran, angket kebutuhan peserta didik terhadap bahan ajar dan hasil wawancara dengan guru matematika yang menyangkut kendala kendala di lapangan. Selanjutnya data setelah buku ajar selesai dibuat. Data ini berupa angket validasi oleh para ahli, guru matematika dan peserta didik. Penelitian ini menggunakan data kuantitatif, data kuantitatif menyangkut validitas, keefektifan dan kepraktisan instrumen pembelajaran yang dikembangkan (Kharisma \& Sugiman, 2017) dengan instrumen berupa Kuesioner yang didalamnya berisi pernyataan dan pertanyaan secara tertulis kepada responden untuk mendapatkan jawaban. Pengisian kuesioner ini merupakan teknik mengumpulkan data. (Sugiono, 2012) Instrumen yang dikembang merupakan adaptasi dari peneliti sebelumnya ( Selibauti, \& Karim, 2018).

Skala Guttman dan skala Likert digunakan sebagai dasar pada Instrumen pengumpulan data. Skala Guttman digunakan untuk Angket pengalaman selama mengikuti pembelajaran matematika dan mengetahui tanggapan peserta didik terhadap bahan ajar yang digunakan di sekolah karena skala Guttman ini hanya memerlukan jawaban"ya dan tidak" (Masruroh, 2015). Kemudian skala Likert untuk data validasi. Data kuantitatif yang diperoleh dianalisis dengan menggunakan teknik deskriptif untuk mengetahui kevalidannya.

Proses analisis mengikuti maksud penelitian. Untuk mulai dengan memvalidasi model atau produk yang digunakan dalam konteks dari penelitian (Shroff, Thou Ting, \& Lam, 2019) Untuk mengetahui hasil interval rata-rata skor dan kategori kelayakan dari penilaian Bahan ajar yang telah divalidasi oleh ahli materi Bidang studi matematika, maka dilakukan penghitungan
Untuk mengetahui kelayakan produk ini sangat diperlukan Teknik analisis data. Analisis ini untuk mengetahui seberapa jauh produk ini memenuhi persyaratan penggunaan, dengan menggunakan analisis deskriptif kuantitatif. Hasil validasi atau Penilaian Produk dari Ahli Media, Ahli Materi, guru, dan siswa dianalisis menggunakan langkah langkah yang ditempuh yaitu: mengubah data kuantitatif dari skala Likert yang berupa lembar penilaian ahli media, ahli materi, guru matematika, dan peserta didik diubah menjadi data kualitatif.

Selanjutnya, menyajikan seluruh data yang telah diubah dalam bentuk tabel dari setiap komponen.

Setelah itu melakukan perhitungan skor total rata-rata dari setiap komponen ke dalam rumus

$$
\bar{X}=\frac{\sum x}{n}
$$

Keterangan

$$
\begin{gathered}
\bar{X}=\text { skor rata rata } \\
\sum_{n=\text { jumlah subyek penelitian }} x=\text { jumlah skor }
\end{gathered}
$$

Skor yang didapat diubah dalam bentuk persentase dengan rumus dibawah ini;

$$
p=\frac{f}{n}
$$

Keterangan:

$\mathrm{P}=$ Persentase

$f=$ Skor yang diperoleh

$n=$ Skor Keseluruhan

skor rata-rata yang didapat diubah menjadi nilai dalam kategori. sehingga, hasil akhir tidak lagi berupa data kuantitatif, tetapi dalam bentuk kualitatif dengan kategori.

Konversi data kuantitatif menjadi data kualitatif menggunakan teori Sukardjo seperti disajikan pada Tabel 1 dalam (Januarisman \& Ghufron, 2016)

Hasil akhir Produk pengembangan yang dihasilkan dikatakan layak jika masingmasing komponen memenuhi kategori baik (Lasmiyati \& Harta, 2014) 
Tabel 1 Konversi Data Kuantitatif Berdasarkan Teori Sukardjo

\begin{tabular}{clcc}
\hline Nilai & Rentang Skor & Persentase & Data Kualitatif \\
\hline A & $X>4,2$ & $81 \%-100 \%$ & Sangat Layak \\
\hline B & $3,4<X \leq 4,2$ & $61 \%-80 \%$ & Layak \\
\hline C & $2,6<X \leq 3,4$ & $41 \%-60 \%$ & Cukup layak \\
\hline D & $1,8<X \leq 2,6$ & $21 \%-40 \%$ & Kurang Layak \\
\hline E & $\leq 1,8$ & $0 \%-20 \%$ & Tidal Layak \\
\hline
\end{tabular}

\section{HASIL DAN PEMBAHASAN}

Pengembangan bahan ajar ini menggunakan prosedur pengembangan Borg dan Gall dengan empat tahapan, yaitu mengumpulkan informasi, merencanakan, mengembangkan produk terakhir melakukan Uji coba produk dan revisi produk akhir. Pada tahap pertama yaitu pengumpulan informasi peneliti melakukan wawancara, observasi dan penyebaran angket kepada peserta didik untuk mengidentifikasi kebutuhan. Hasil yang diperoleh dari angket pengalaman belajar peserta didik dengan 33 responden adalah (1)mengikuti proses yang diajarkan guru , yaitu $81,82 \%$, (2) suka belajar matematika yang kontekstual $72,7 \%$, (3) suka belajar matematika dengan memecahkan masalah $81,8 \%$, (4) selalu dapat menemukan solusi dari suatu masalah matematika 51,5\%, (5) mengalami kesulitan bila mengaitkan berbagai konsep dalam matematika 18,18\% (6)mengalami kesulitan bila memberikan alasan, bukti atau argumen yang bersifat logis $21,2 \%$, (7) mengalami kesulitan bila membuat ringkasan matematika menggunakan bahasa sendiri 24,2\%, (8) terbiasa menyelesaikan soal cerita yang panjang yang memerlukan penalaran $18,18 \%$.

Aspek aspek yang rendah itu adalah bagian dari komponen berpikir tingkat tinggi.
Menyangkut kebutuhan buku (1)sebanyak $66,67 \%$ responden menyatakan kurang memahami materi bilangan, (2) memahami materi dalam buku teks tanpa penjelasan dari guru $42,42 \%$, (3) membutuhkan sumber belajar lain untuk menunjang kegiatan belajar $87,87 \%$, (4) membutuhkan sumber belajar lain yang dapat dipahami secara mandiri 90,9\%

Berdasarkan hasil wawancara guru matematika ibu Suntari, S.Pd M.Si didapatlah beberapa informasi, diantaranya peserta didik masih mengalami banyak kesulitan saat menyelesaikan soal dari materi Bilangan . Peserta didik cenderung menyelesaikan soal soal yang level mengingat dan memahami dari pada soal soal yang membutuhkan penalaran. Sedangkan merujuk penelitian sebelumnya tentang analisis buku siswa buku BSE kurikulum 2013 edisi revisi menyatakan soal-soal pada BSE didominasi domain kognitif kategori knowing sebesar 52.50\% applying dan reasoning lebih dilatihkan pada buku siswa Kurikulum 2013 (Muklis \& Oktora , 2015). Tahap selanjutnya perencanaan dan pengembangan produk. Produk yang dihasilkan berupa buku ajar matematika materi Bilangan Berbasis Higher Order Thinking Skills yang mempunyai susunan seperti berikut;

Tabel 2 Tabel gambaran Isi Buku Ajar

\begin{tabular}{llcc}
\hline No & \multicolumn{1}{c}{ Isi Keseluruhan Buku } & \multicolumn{2}{c}{ Bentuk Dokumen } \\
\cline { 3 - 4 } & & Teks & Gambar \\
\hline 1 & Sampul Awal dan Sampul Belakang & $\mathrm{V}$ & $\mathrm{V}$ \\
\hline 2 & Kata Pengantar & $\mathrm{V}$ \\
\hline 3 & KI dan KD & $\mathrm{V}$ \\
\hline 4 & Daftar Isi & $\mathrm{V}$ \\
\hline
\end{tabular}




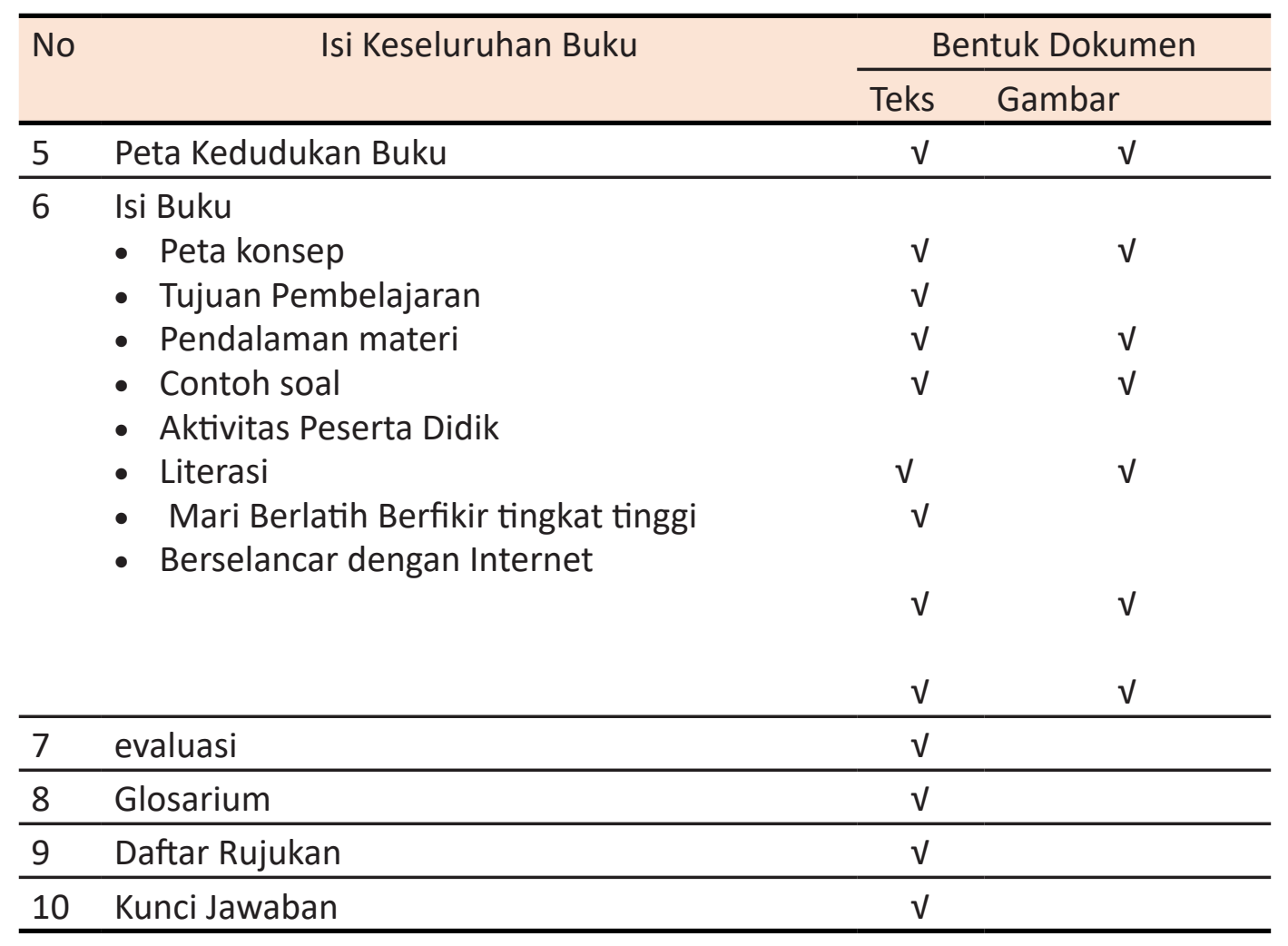

Contoh beberapa bagian dari buku ajar ini :

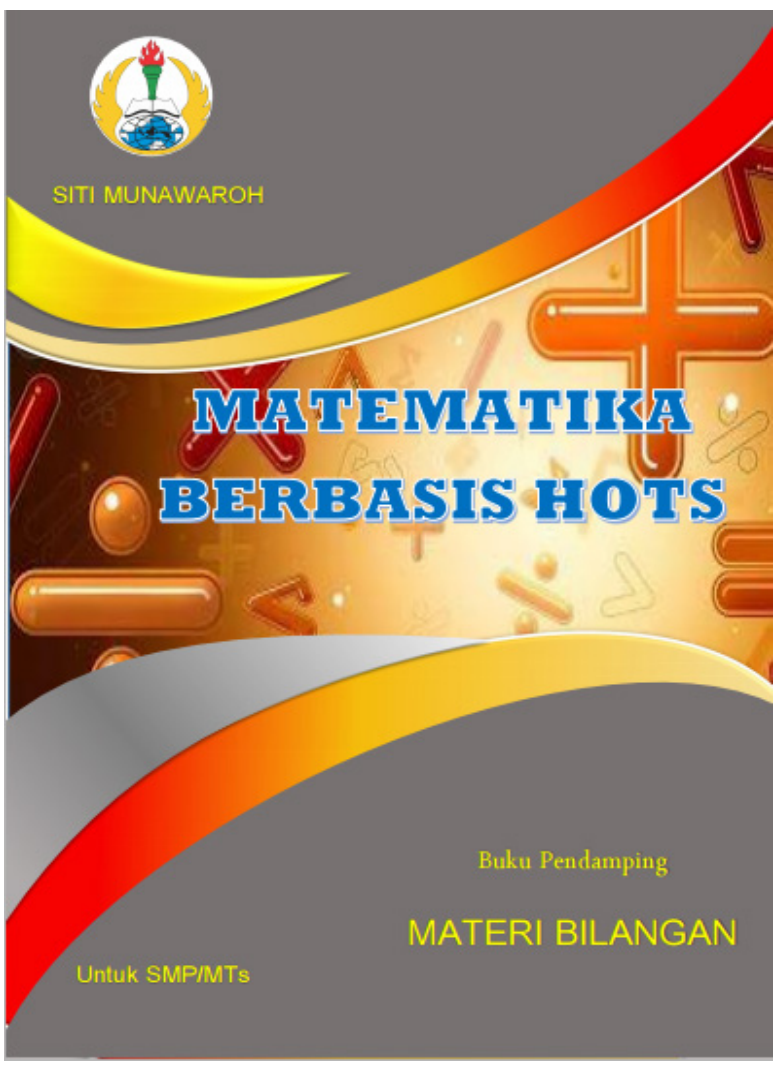

Gambar 2 Tampilan Cover Buku Matematika BerBasis HOTS
Orientasi sitwa pada masaloh

Pass bacian ini kea akan memperkapa lagi mencenai unvean bilunca bulat

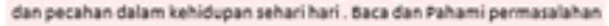
berikut!

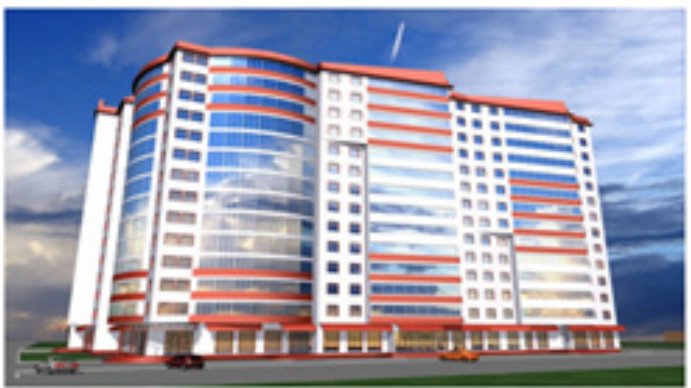

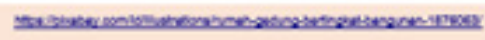
Sebuah lanoo bertartai 25 mempuryai 3 tanai berada 6 bawak wnak Seerang laryaran mubemub berata di lantai 2 lanor ha unok melabian Rutintasnya Kavena ada suanu keperivan, a wrun 4 brad, kemudian nak 11 broi untik betiemu Kepala Depantemen HRD MHuman Resources Development. sulang beberapa saat ada pangilan meting di lantai is

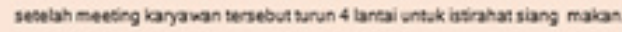
Sestah selessi istrahat kayawan in kembali ke kantor nja urtuk melanjulan

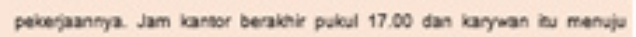
Masalah 1

Dechatias posidi karywan gedung tersebut berkensentrasian dengan pergerskan karyawan tersebut. Caputicah kamu menentukan posisi karyawan

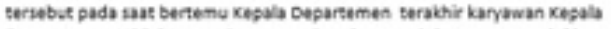
Departermen mab (Muman sesburces Development) deacan menuriuliad cambar

\section{Gambar 3 Contoh Aktivitas Peserta didik} Pembelajaran Berbasis masalah 


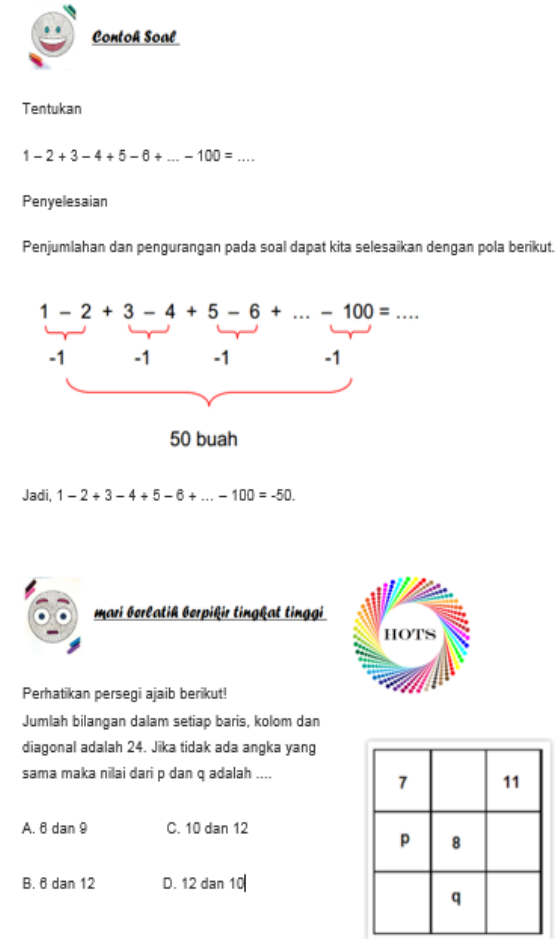

\section{Gambar 4 Contoh Latihan Berpikir kritis dan kreatif}

\section{Hasil Uji Ahli Materi Matematika}

Hasil pengembangan bahan ajar matematika materi Bilangan Berbasis Higher Order Thinking Skills yang berupa buku sudah diselesaikan, selanjutnya direview oleh ahli materi untuk sekiranya mendapat tanggapan, penilaian dan saran saran sebagai bahan perbaikan. Review ini menggunakan angket atau kuesioner yang telah disusun oleh peneliti, review dilakukan 2 kali yaitu tahap ke-1 dan tahap ke-2. Pada tahap ke-2 adalah tahap setelah menerima masukan dari reviewer. Reviewer ahli materi adalah Bapak Dr. H. Ibut Priono Leksono, M.Pd, dosen Pascasarjana Universitas PGRI Adi Buana. Skor rata rata diperoleh dari jumlah masing masing indikator dalam satu aspek dibagi banyak subjek penelitian dari aspek tersebut , kemudian dikonversi dalam persentase selanjutnya disesuaikan dengan tabel Tabel Konversi data Kuantitatif Berdasarkan Teori Sukardjo

Tabel 3 Data Hasil Keseluruhan Penilaian dan Validasi Oleh Ahli Materi/isi

\begin{tabular}{|c|c|c|c|c|}
\hline Tahap & No & Aspek penilaian & $\begin{array}{l}\text { Skor rata } \\
\text { rata }\end{array}$ & Kategori \\
\hline \multirow[t]{4}{*}{1} & 1 & Aspek Kesesuaian Tujuan & 4 & Layak \\
\hline & 2 & Aspek Kelayakan isi & 4,2 & Layak \\
\hline & 3 & Aspek Kelengkapan materi & 4,1 & Layak \\
\hline & 4 & Aspek Kelengkapan evaluasi atau tes & 4, & Layak \\
\hline \multirow[t]{4}{*}{ II } & 1 & Aspek Kesesuaian Tujuan & 4,75 & Sangat layak \\
\hline & 2 & Aspek Kelayakan isi & 4,9 & Sangat layak \\
\hline & 3 & Aspek Kelengkapan materi & 4,7 & Sangat layak \\
\hline & 4 & Aspek Kelengkapan evaluasi atau tes & 4,75 & Sangat layak \\
\hline \multicolumn{3}{|c|}{ Skor rata rata Tahap I } & 4,07 & Layak \\
\hline \multicolumn{3}{|c|}{ Skor rata rata Tahap II } & 4,77 & Sangat Layak \\
\hline
\end{tabular}

Berdasarkan tabel skor rata-rata dari 4 aspek yang dinilai oleh ahli materi, dapat disimpulkan bahwa terdapat peningkatan pada tiap aspek yang dinilai. Pada tahap 1 diperoleh skor rata-rata 4,07 dengan kategori "Layak", tahap 2 setelah berdasarkan masukan, tanggapan dan penilaian tahap pertama memperoleh kenaikan 0,7 skor rata-rata 4,77 dengan kategori "Sangat Layak, pada tahap pertama revisi dilakukan pada aspek Tujuan pembelajaran disini terdapat masukan berupa kejelasan tujuan pembelajaran lebih terperinci pada setiap kegiatan pembelajaran, masih ada beberapa bagian yang harus disesuaikan antara materi dengan tujuan pembelajaran, relevansi 
antara materi dengan tujuan pembelajaran pada tiap tiap Kompetensi Dasar. Pada aspek kelayakan isi terdapat masukan untuk perbaikan di Kesesuaian penulisan daftar isi dengan isi buku teks, Kemudahan memahami peta konsep, Ketepatan penempatan unsur tata letak (topik, sub topik, dan ilustrasi). Pada Aspek Kelengkapan evaluasi atau tes masukan berupa evaluasi disertai kunci jawaban, pada Aspek Kelengkapan materi masukannya adalah Kedalaman materi perlu diperdalam kembali dengan contoh dan uji coba, sehingga pemahaman siswa lebih luas dalam hal ini peneliti memberi tautan Barcode yang intinya memberi keluasan materi lewat video pembelajaran, bahan literasi, soal soal UNBK tahun lalu.

\section{Hasil Uji Ahli Desain Pembelajaran}

Produk pengembangan bahan ajar matematika materi Bilangan Berbasis Higher Order Thinking Skills sudah diselesaikan, selanjutnya direview oleh ahli Desain pembelajaran untuk sekiranya mendapat tanggapan, penilaian dan saran saran sebagai bahan perbaikan. Review inimenggunakan angket atau kuesioner yang telah disusun oleh peneliti, review dilakukan 2 kali yaitu tahap 1 dan tahap 2. Pada tahap 2 adalah tahap setelah menerima masukan dari reviewer. Reviewer ahli materi adalah Bapak Dr. H. Ibut Priono Leksono, M.Pd, dosen Pascasarjana Universitas PGRI Adi Buana. Skor rata rata diperoleh dari jumlah masing masing indikator dalam satu aspek dibagi banyak subjek penelitian dari aspek tersebut, kemudian dikonversi dalam persentase selanjutnya disesuaikan dengan tabel Tabel Konversi Data Kuantitatif Berdasarkan Teori Sukardjo

Tabel 4 Data Hasil Keseluruhan Penilaian dan Validasi Oleh Ahli Desain

\begin{tabular}{lllll}
\hline Tahap & No & Aspek penilaian & Skor rata rata & Kategori \\
\hline I & 1 & Aspek Desain Sampul & 3,75 & Layak \\
\cline { 2 - 5 } & 2 & Aspek Desain Isi & 4,1 & Layak \\
\hline II & 1 & Aspek Desain Sampul & 4,75 & Sangat layak \\
\cline { 2 - 4 } & 2 & Aspek Desain Isi & 4,7 & Sangat layak \\
\hline Skor rata rata Tahap I & 3,8 & Layak \\
\hline Skor rata rata Tahap II & 4,4 & Sangat Layak \\
\hline
\end{tabular}

pada tabel skor rata-rata di atas, dapat disimpulkan bahwa terdapat peningkatan skor hasil penilaian dari penilaian tahap $1 \mathrm{ke}$ penilaian tahap 2. Skor rata-rata penilaian tahap 1, yaitu 3,8 dengan kategori "Layak". Sedangkan skor rata-rata penilaian tahap 2, yaitu 4,4 dengan kategori "Sangat Layak". Peningkatan terjadi berdasarkan revisi yang telah dilakukan peneliti terhadap Buku yang dikembangkan. Revisi yang dilakukan pada Sampul belum menggambarkan isi serta warna unsur dan tata letak kurang harmonis.
Pada aspek Desain isi, perbaikan atau revisi yang harus dilakukan peneliti, yaitu mengganti Font yang dianggap menyulitkan membaca

\section{Hasil Uji Guru Matematika}

Setelah dilakukan review dari ahli materi dan ahli desain pembelajaran bahan ajar ini direvisi sesuai masukan yang diterima. Kemudian buku ajar di review oleh teman sejawat yaitu guru matematika di SMP Negeri 20 Surabaya. Adapun hasil dari review tersebut adalah 
Tabel 5 Keseluruhan Data Hasil Penilaian dan Validasi Tiap Aspek oleh Guru Matematika

\begin{tabular}{lllll}
\hline No & Aspek penilaian & Skor rata rata & Persentase & Kategori \\
\hline 1 & Aspek Kesesuaian Tujuan & 3,75 & $75 \%$ & Layak \\
\hline 2 & Aspek Kelayakan isi & 3,9 & $78 \%$ & Layak \\
\hline 3 & Aspek Kelengkapan materi & 4 & $80 \%$ & Layak \\
\hline 4 & Aspek Kelengkapan evaluasi atau tes & 3,75 & $75 \%$ & Layak \\
\hline 5 & Aspek Desain Sampul & 3,75 & $75 \%$ & Layak \\
\hline 6 & Aspek Desain isi & 3,9 & $78 \%$ & Layak \\
\hline Skor rata rata & 3,84 & $77 \%$ & Layak \\
\hline
\end{tabular}

Berdasarkan tabel data hasil penilaian oleh guru matematika keenam aspek mendapat predikat Layak, rata rata keseluruhan aspek memperoleh skor rata-rata 3,84 dengan persentase $77 \%$ berkategori "Layak".

Banyaksekalimasukandarimatematika selaku pelaku dalam proses pengajaran yang mengetahui titik titik penting pada sebuah bahan ajar. Masukan dari guru matematika pada aspek tujuan lebih difokuskan pada tujuan tiap sub pokok bahasan, masukan lain desain sampul yang penataan nya terlalu padat, guru matematika mengapresiasi model pembelajaran yang mengarahkan peserta didik membiasakan berpikir kreatif. Masukan dari guru matematika dijadikan bahan untuk revisi 2 sebagai perbaikan produk

Dari uraian hasil penilaian validator dapat disusun Data secara Keseluruhan Hasil Penilaian dan Validasi Ahli Desain, Ahli Materi, dan Guru matematika Berikut tabel keseluruhan skor rata-rata penilaian dan validasi oleh ahli media, ahli Desain , dan guru matematika

Tabel 6 Keseluruhan Data Hasil Penilaian Oleh Ahli Desain , Ahli Materi, dan Guru Matematika

\begin{tabular}{|c|c|c|c|c|}
\hline No & Penilai & Skor rata-rata & Kategori & ingkat kelayakan \\
\hline 1 & Ahli Desain & 4,4 & Sangat Layak & $88 \%$ \\
\hline 2 & Ahli Isi & 4,7 & Sangat layak & $84 \%$ \\
\hline 3 & Guru Matematika & 3,84 & Layak & $77 \%$ \\
\hline \multicolumn{2}{|c|}{ Rata rata Skor } & 4,3 & Sangat Layak & $86 \%$ \\
\hline
\end{tabular}

Dari rata rata skor Validasi Ahli Desain, Ahli Materi, dan Guru matematika diperoleh skor 4,3. Skor yang didapat data kemudian dilakukan pengkonversian data kuantitatif menjadi data kualitatif menggunakan teori Sukardjo . hasil yang diperoleh dalam kategori "Sangat Layak"

\section{Uji Coba Skala Kecil}

Meskipun buku ajar ini sudah dikategorikan sangat layak akan tetapi semua masukan dari guru matematika tetap dipertimbangkan sehingga dilakukan revisi ke-2 dari produk buku ajar ini. Untuk mengetahui kelayakan nya maka produk buku ajar ini diuji cobakan dalam skala kecil di satu sekolah. Pengujian produk dilakukan di SMP Negeri 20 Surabaya dengan banyak subjek adalah 5 orang peserta didik. Data hasil pengujian terhadap peserta didik kelas VII SMP ini merupakan data paling ujung yang diperoleh setelah penilaian dilakukan oleh ahli media, ahli materi, dan guru Matematika. Mengenai respon atau tanggapan peserta didik kelas VII SMP adalah sebagai batasan pengujian buku ajar yang dikembangkan dan merupakan hasil terakhir penilaian kelayakan produk. Berdasarkan data hasil pengujian oleh peserta didik, didapatkan skor rata-rata seperti pada Tabel 7. 
Tabel 7 Keseluruhan Data Hasil Penilaian Tiap Aspek oleh Peserta didik Kelas VII

\begin{tabular}{llccc}
\hline No & Aspek penilaian & Skor rata rata & Persentase & Kategori \\
\hline 1 & Aspek Kesesuaian Tujuan & 4,6 & $92 \%$ & Sangat Layak \\
\hline 2 & Aspek Desain Sampul & 4,5 & $90 \%$ & Sangat Layak \\
\hline 3 & Aspek Desain isi & 4,5 & $90 \%$ & Sangat Layak \\
\hline 4 & Aspek Kelayakan isi & 4,6 & 92 & Sangat Layak \\
\hline 5 & Aspek Kelengkapan materi & 4,5 & $90 \%$ & Sangat Layak \\
\hline 6 & $\begin{array}{l}\text { Aspek Kelengkapan evaluasi } \\
\text { atau tes }\end{array}$ & 4,48 & 89,6 & Sangat Layak \\
\hline $\begin{array}{l}\text { Skor } \\
\text { rata } \\
\text { rata }\end{array}$ & 4,53 & $90 \%$ & Sangat Layak \\
\hline
\end{tabular}

Dari hasil pengujian di lapangan dalam skala kecil aspek kesesuaian tujuan dengan skor 4,2 dalam kategori sangat layak, aspek Desain sampul mendapat skor 4,5 dalam kategori sangat layak, demikian dengan aspek aspek yang lain mendapat tanggapan yang sangat layak terhadap bahan ajar Berbasis Hots pada materi Bilangan. Hasil perolehan semua Penilaian dari ahli materi, ahli Desain, guru matematika dan peserta didik terdapat pada Tabel dibawah ini

Tabel 8 Data hasil Keseluruhan penilaian

\begin{tabular}{|c|c|c|c|c|c|}
\hline No & $\begin{array}{c}\text { Aspek } \\
\text { penilaian }\end{array}$ & $\begin{array}{l}\text { Ahli } \\
\text { Desain }\end{array}$ & $\begin{array}{c}\text { Ahli } \\
\text { Materi }\end{array}$ & $\begin{array}{c}\text { Skor rata rata } \\
\text { guru }\end{array}$ & Peserta didik \\
\hline
\end{tabular}

\begin{tabular}{llccc}
\hline 1 & Aspek Kesesuaian Tujuan & 4,75 & 3,75 & 4,6 \\
\hline 2 & Aspek Kelayakan isi & 4,9 & 3,9 & 4,5 \\
\hline 3 & Aspek Kelengkapan materi & 4,7 & 4 & 4,5 \\
\hline 4 & $\begin{array}{l}\text { Aspek Kelengkapan evaluasi } \\
\text { atau tes }\end{array}$ & 4,75 & 3,75 & 4,48 \\
\hline 5 & Aspek Desain Sampul & 4,75 & 3,75 & 4,5 \\
& & 4,7 & 3,9 & 4,5 \\
\hline 6 & Aspek Desain isi & 4,72 & 4,77 & 3,8 \\
\hline Skor rata rata & & & & \\
\hline
\end{tabular}

\section{Pembahasan}

Untuk mengetahui kelayakan sebuah buku ajar dikatakan layak jika mendapatkan persentase hasil penilaian sebesar $60 \%-80 \%$. Selanjutnya dinyatakan sangat layak digunakan apabila buku mendapatkan tingkat kelayakan sebesar $81 \%-100 \%$ ( Selibauti, \& Karim, 2018)

Berdasarkan hasil analisis data secara keseluruhan oleh (1) ahli desain mendapatkan skor rata rata 4,72 dengan persentase $94,4 \%$ jika di konversi ke tingkat pencapaian dengan kualifikasi produk pengembangan ditafsirkan dalam kategori Sangat layak. (2) Ahli materi dengan skor rata rata 4,77 persentase $95,4 \%$ sesuai konversi tingkat pencapaian kualifikasi in ditafsirkan dalam kategori Sangat layak. (3) Guru Matematika dengan skor rata rata 3,8 sesuai konversi tingkat pencapaian kualifikasi 
produk ditafsirkan dalam kategori layak (4) peserta didik memberi penilaian 4,51 sesuai konversi tingkat pencapaian kualifikasi produk ditafsirkan dalam kategori sangat layak

Berdasarkan penilain secara keseluruhan rata rata dari

Adalah 4,45 dengan persentase $89 \%$

biladikonversitingkat pencapaiankualifikasi produk, Data Kuantitatif Berdasarkan Teori Sukardjo diperoleh interpretasi dalam kateri "A" Sangat Layak. Meskipun sudah dinyatakan sangat layak, tapi peneliti masih tetap menindaklanjuti saran-saran yang diberikan oleh penilai, demi perbaikan produk.

Berdasarkan penelitian-penelitian yang sebelumnya yang merajuk pada pembelajaran HOTS yang menyatakan keterampilan Berpikir sangat penting karena merupakan bagian integral dari kegiatan dan peristiwa kognitif "Findings indicating that cognitive skills fluctuate as a function of the situation, suggest that thinking skills, per se, are limited in their generality and that "context is an integral aspect of cognitive activities and events, not a nuisance variable" (Rogoff \& Lave, 1984, $\mathrm{hlm} .1$ ) dalam (Morrison, 2003). Tugas guru adalah tidaklah mudah. Dalam penelitian ini menyadari, begitu penting maka perlu disusun instrumen yang mendukung seperti bahan ajar. Instrumen yang handal dan valid untuk mengukur persepsi aktif siswa belajar dalam konteks pembelajaran yang didukung teknologi sangat penting (Shroff, Thou Ting, \& Lam, 2019)

Penelitian bahan ajar dari (Suarman, Hendripides, \& Hikmah, 2018) Hasil penilaian ahli dari materi dengan skor rata-rata $89,47 \%$ (sangat baik) dan hasil tanggapan siswa dengan skor rata-rata $86,45 \%$ (sangat baik), dengan demikian bahan ajar layak digunakan dalam pembelajaran Hasil penelitian ini juga menambah bukti empiris bahwa bahan ajar dibutuhkan oleh mahasiswa sebagai pedoman atau panduan dalam kegiatan perkuliahan

Studi penelitian lain yang menunjukkan dampak peningkatan prestasi setelah kurun waktu tertentu menggunakan pembelajaran HOTS dilakukan di luar negeri Siswa menghabiskan sekitar 30-40 menit setiap minggu bekerja pada latihan pemetaan menggunakan sistem. Hasilnya menggembirakan; siswa menunjukkan mengalami peningkatan rata-rata 0,45 standar deviasi pada tes standar pemikiran kritis selama semester. Hasil ini lebih baik dibandingkan dengan yang diperoleh dalam studi lain dari program pemikiran kritis dan secara signifikan lebih tinggi dari keuntungan yang diharapkan dari 0,1 standar deviasi yang diharapkan dihasilkan dari satu semester tanpa instruksi pemikiran kritis. (Butchart,, Forster, Gold, \& Bigelow, 2009).

Studi lain tentang kelayakan bahan ajar HOTS dikembangkan oleh Chintia Tri Noprinda dari Universitas Islam Negeri Raden Intan Lampung hasil penelitiannya adalah Respons guru terhadap LKPD yang dikembangkan diperoleh rata-rata skor $88 \%$ dengan kriteria "sangat baik". Respons peserta didik terhadap LKPD diperoleh rata-rata skor $87 \%$ dengan kriteria "sangat baik", tahap validasi oleh ahli materi,ahli media dan uji coba telah mencapai standar kelayakan dan layak untuk digunakan peserta didik. Jadi, LKPD pembelajaran fisika berbasis Higher Order Thinking Skill (HOTS) pada materi Listrik Statis kelas IX siap dipakai sebagai bahan ajar (Noprinda \& Soleh, 2019). Peneliti lain juga mengembangkan bahan ajar HOTS yaitu Charanjit Kaur Swaran Singh dan Rhashvinder Kaur Ambar Singh dari malaysia hasil penelitiannya adalah keterampilan berpikir tingkat tinggi yang digunakan oleh para guru dalam penelitian ini memiliki efek positif belajar siswa menggunakan modul HOTS. Menggunakan modul HOTS dalam pembelajaran dapat mendorong interaksi sosial (Swaran, Ambar, Masa , \& Mostafa, 2018).

\section{SIMPULAN}

Setelah tahap demi tahap penelitian dilalui dari mulai pengumpulan data, perencanaan, pengembangan produk dan akhirnya Uji coba dan revisi produk akhir, semua data yang sudah dikonversi menunjukkan. hasil penilaian dan validasi oleh ahli desain, ahli materi, guru dan peserta didik disimpulkan bahwa secara keseluruhan hasil penilaian memperoleh rata-rata skor 4,45 dengan persentase $89 \%$ berkategori "Sangat Layak". Hasil ini menunjukan bahwa Buku pembelajaran matematika 
berbasis HOTS (Higher Order Thinking Skills) yang dikembangkan peneliti sangat layak digunakan sebagai bahan ajar tambahan Dengan demikian dapat ditarik kesimpulan bahwa Buku pembelajaran matematika materi Bilangan berbasis HOTS (Higher Order Thinking Skills) untuk peserta didik kelas VII SMP "Sangat Layak" digunakan.

Produk pengembangan ini adalah buku ajar yang berjudul "Buku Matematika Materi Bilangan Berbasis HOTS" buku ini layak dipakai sebagai buku pendamping guru yang merupakan buku sumber belajar pendamping guru untuk aktivitas di sekolah. Produk ini adalah produk bahan ajar ini bersifat subjektif dalam mengembangkan tema-tema yang ada hubungannya dengan hasil analisis si pengembang. Kondisi siswa dan sekolah menyesuaikan dengan kondisi riil di lapangan. Pengguna produk bahan ajar ini diperlukan adaptasi dan pemahaman yang penuh dan disesuaikan dengan keadaan sekolah masing masing

Selain itu bahan ajar ini tidak dimaksudkan untuk menjadi buku pegangan utama guru, tetapi dipergunakan bersama-sama bahan ajar yang lain. Saran dari pengembang untuk para pendidik dan pengembang lain adalah untuk menyiapkan peserta didik yang siap menghadapi tantangan masa depan adalah dengan menyiapkan pembelajaran yang berbasis HOTS (Higher Order Thinking Skills)yang melatih peserta didik untuk mengembangkan kompetensianalitis, mengembangkan keterampilan berpikir kritis, dan mengembangkan kemampuan komunikasi

\section{REFERENSI}

Alfa, y. (2017, Mei 19). Revisi Kurikulum 2013. Dipetik Oktober 22, 2019, dari kompasiana.com: https://www. kompasiana.com/ysfalfan/591dfeb81b afbd2c7f4a3ee0/revisi-kurikulum-2013

Ariyana, Y., Pudjiastuti, A., Bestary, R., \& Zamroni,. (2019). Buku Pegangan Pembelajaran Berorientasi pada Ketrampilan Berpikir Tingkat Tinggi. Jakarta: Direktorat Jenderal Guru dan Tenaga Kependidikan.

Asy'ari, A. R., Ali, M., Basri, H., Kurniati, D., \&
Maharani, S. (2019). Mengembangkan HOTS (High Order Thinking Skills)). Malang: Universitas Negeri Malang.

Brookhart, S. M. (2010). How to Assess Higher Order Thinking Skill in your classroom. Dalam How to Assess Higher Order Thinking Skill in your classroom (hal. 3). Alexandaria Virginia USA: ASDC.org.

Butchart,, S., Forster, D., Gold, I., \& Bigelow, J. (2009). Improving critical thinking using web based argument mapping exercises with automated feedback. Australasian Journal ofEducational Technology, 25(2), 268-291.

Daryanto, \& S. k. (2017). Pembelajaran Abad 21 (1 ed.). Yogyakarta: Gava media.

Degeng, N. S., \& Degeng, P. D. (2018). IImu Pembelajaran. yogyakarta: Yayasan Taman Pustaka Kristen Indonesia.

Emzir, A. (2011). Metodologi Penelitian Kualitatif Analisis Data. Jakarta: Rajawali Press.

Fisher, A. (2009). Berpikir Kritis: Sebuah Pengantar. Jakarta: Erlangga.

Hanik, U., Mardiyana, I. I., \& Rosid, A. (2020, April 19). Peningkatan Kompetensi Guru dalam Mengintegrasikan. Jurnal IImiah Pengabdhi, 6(1). doi:DOI: https://doi. org/10.21107/pangabdhi.v13i1.7101

Harrison, N. (2013). Using the interactive whiteboard to scaffold a metalanguage: Teaching higher order thinking skills in preservice teacher education. Australasian Journal of Educational Technology, 2013, , 29(1). doi:DOI: https://doi.org/10.14742/ajet.48

Harususilo, Y. E. (2018, 11 09). Mendikbud Imbau Guru Kembangkan Pembelajaran HOTS. Diambil kembali dari edukasi. kompas.com.

Januarisman, E., \& Ghufron, A. (2016, Oktober). Pengembangan Media Pembelajaran Berbasis WEeb Mata Pelajaran IImu Pengetahuan Alam Untuk Siswa Kelas VII. (U. N. Yogyakarta, Penyunt.) Jurnal Inovasi Teknologi Pendidikan, 3(2), 166182.

Kharisma, J. Y., \& Sugiman. (2017). Pengembangan Bahan Ajar Matematika Berbasis Masalah Berorientasi Kemampuan Pemecahan Masalah 
dan Prestasi Belajar Matematika. Jurnal Pendidikan Matematika dan Sains, 5(2), 142-151. doi:http://dx.doi. org/10.21831/jpms.v4i1.10111

Krulik, S., Rudnick, J., \& Mileo, E. (2003). Teaching Mathematics in Middle Schools, A Practical Guide. Boston: Pearson Education, Inc.

Kurbaita, G., Zulkardi , \& Siroj, R. (2013, Juni). Pengembangan Buku Ajar Matematika Tematik Integratif. JURNAL KREANO,, 4(1). Dipetik januari 13, 2020, dari https://journal.unnes.ac.id/nju/index. php/kreano/article/view/2877/2963

Lasmiyati, \& Harta, I. (2014, Desember). Pengembangan Modul Pembelajaran untuk Meningkatkan Pemahaman Konsep. PYTHAGORAS: Jurnal Pendidikan Matematika dan Minat SMP, 9(2), 161-174.

MacKinnon, G. R., \& Aylward, M. L. (2009). Models for Building Knowledge in a Technology-Rich Setting: Teacher Education. Canadian Journal of Learning and Technologi , 35(1). doi:https://doi. org/10.21432/T2388Q

Masruroh, A. (2015). Pengembangan Modul Pembelajaran Menulis Cerpen. Yogyakarta: Fakultas Bahasa dan Seni Universitas Negeri Yogyakarta .

Morrison, D. (2003). Using Activity Theory to Design Constructivist Online Learning Environments for Higher Order Thinking: A Retrospective Analysis. Canadian Journal of Learning and Technology. doi:https://doi.org/10.21432/T2X01R

Muklis, Y. M., \& Oktora, S. R. (2015, 5 10). Analisis Deskriptif Soal-soal Dalam Buku Siswa Kurikulum 2013 (Edisi Rrevisi) DAN BSE Pelajaran Matematika SMP Kelas VII. Publikasi IImiah UMS. Diambil kembali dari http://hdl.handle. net/11617/6132

Mursant, A. E., Fatirul,, A. N., \& Hartono. (2020, April). Pengembangan Bahan Ajar Dasar Tata Rias Wajah untuk Mahasiswa Prodi Pendidikan Vokasional Kesejahteraan Keluarga (PVKK) Tata Rias. (edcomtech, Penyunt.) Jurnal Kajian Teknologi Pendidikan, 5(1), 76-87.

Noprinda, C. T., \& Soleh, S. M. (2019,
Juli). Development Of Student WorksheetBased On Higher Order Thinking Skills(HOTS). Indonesian Journal of Science and Mathematics Education, 2(2), 168-176. doi:10.24042/ IJSME.V212.4342

Pellini, A. (2016, Desember 16). Indonesia's PISA results show need to use education resources more efficiently. Dipetik September 29, 2019, dari thejakartapost.

Puspitasari, D. E. (2017, November 07). Pengembangan Bahan ajar Booklet Komik 3 Dimensi Tema 2 Selalu Berhemat Energi Pada SiswaKelas IV SDN Sukodadi 1 Paton. UMM Institutional Repository. doi:http://eprints.umm.ac.id/35586/

Qolbi, M. S., Thaariq, Z. Z., Az-Zahroh, S. F., Anwar, M. M., \& Faiza, N. (2019). Design and Development of Game Based Learning Applications for Mathematics Learning Based on Multiple Language to Develop Verbal Capabilities. JPP (Jurnal Pendidikan dan Pembelajaran), 26(2), 51-56.

Resnick, L. B. (1987). Education and Learning to Think. Washington, D.C: National Academy Press.

Sadjati, I. M. (2012). Hakikat Bahan Ajar. Dalam IDIK4009/MODUL. Universitas Terbuka Repository. Dipetik Nopember 08, 2019, dari http://repository.ut.ac. id/4157/1/IDIK4009-M1.pdf

Selibauti, , L., \& Karim, M. (2018, Desember 1). Pengembangan Modul Pembelajaran Menulis Puisi Berbasis. Pena:Jurnal Pendidikan dan Sastra, Vol 8 (No. 1 ). doi:https://doi.org/10.22437/pena. v8i1.6560

Shroff, R. H., Thou Ting, F. S., \& Lam, W. H. (2019). Development and validation of an instrument to measure students' perceptions of technology-enabled active learning. Australasian Journal of Educational Technology, 35(4). doi:https://doi.org/10.14742/ajet.4472

Sitompul, N. C., Leksono, I. P., \& Rufi'i, R. (2019, April 25). Meningkatkan Kompetensi Pendidik di Era Pembelajaran Abad 21 dengan Menjadi Guru Blogger. Jurnal Pemberdayaan Masyarakat, 04(1), 330 
- 338. doi:https://doi.org/10.21067/ jpm.v4i1.3131

Suarman, Hendripides, \& Hikmah, N. (2018). Development of Innovative Teaching Materials through Scientific Approach. Journal of Educational Sciences. Vol. 2, No. 2, 2018, 14-22, 2(2), 14-22. doi:https://fkip.unri.ac.id/wp-content/ uploads/2019/03/JES-2018.pdf

Sugiono. (2012). Metode Penelitian Pendidikan Pendekatan Kuantitatif, Kualitatif, $R \& D$. Bandung: Alfabeta.

Sukmana, Y. (2018, April 13). Permintaan Maaf Mendikbud Setelah Para Siswa SMA Keluhkan Sulitnya Soal UNBK... (I. D. Wedhaswary, Editor, \& kompas) Dipetik September 29, 2019, dari nasional. kompas: https://nasional.kompas. $\mathrm{com} / \mathrm{read} / 2018 / 04 / 13 / 17525781 /$ permintaan-maaf-mendikbud-setelahpara-siswa-sma-keluhkan-sulitnya-soalunbk
Swaran, C., Ambar, R., Masa , T., \& Mostafa, N. (2018, April 9). Developing a Higher Order Thinking Skills Module for Weak ESL Learners. ERIC Institute of Education Sciences, 11(7). doi:10.5539/elt. v11n7p86

Utami, R. E., Nugroho, A. A., Dwijayanti, I., \& Sukarno, A. (2018, September). Pengembangan E-Modul Berbasis Etnomatematika Untuk Meningkatkan Kemampuan Pemecahan Masalah. JNPM (Jurnal Nasional Pendidikan Matematika), 2(2), 268-283. doi:http:// jurnal.unswagati.ac.id/index.php/ JNPM/index

Yektyastuti, R., \& Ikhsan , J. (2016). Pengembangan Media Pembelajaran Berbasis Android pada Materi Kelarutan untuk Meningkatkan Performa Akademik Peserta Didik SMA. Jurnal Inovasi Pendidikan IPA, 2(1), 88-99. Diambil kembali dari https://journal. uny.ac.id/index.php/jipi/article/ view/10289/8072 